\title{
UNIVERZITNÍ VZDĚLÁVÁNÍ V MINULOSTI, SOUČASNOSTI A BUDOUCNOSTI
}

MUŽÍK, J., LÖWENHÖFFEROVÁ, R. A P. KRPÁLEK. 2020. Univerzitní vzdělávání v minulosti, současnosti a budoucnosti. Praha: Professional Publishing, s. 128. ISBN 978-80-88260-45-5.

Monotematickou monografii směřují autoři k vysokoškolským pedagogům, studentům humanitních a společenských věd, učitelům a studentům na středních školách a jejich rodičům, odborníkům v akreditačním procesu i dalším subjektům. Jejím cílem má být reflexe současné situace v univerzitním vzdělávání z globálního, evropského i našeho národního pohledu. Obsah je zpracován v sedmi kapitolách, obsahuje závěrečné poznámky, abstrakty v češtině a angličtině, použitou odbornou literaturu a rejstř́k.

V úvodu je mj. autoři definují „elitní“ a „masové“ vysokoškolské vzdělávání v souvislosti s konferencí OECD z roku 1973, k čemuž se vracejí znovu ve třetí kapitole. Zmiňují Glasgowskou deklaraci z roku 2005 ke zdokonalování činnosti vysokých škol a formulují tři klíčové pilíře vysokých škol, a to výuku, výzkum a další vzdělávání. Autoři konstatují, že dosud přežívají některé prvky klasické univerzity s klasickým didaktickým modelem výuky. To, v čem se univerzity liší, je míra elektronizace - digitalizace výuky.

V první kapitole autoři definují univerzitní vzdělávání a označují ho z ekonomického pohledu za jeden ze základních kamenů lidského kapitálu. Hlavní složkou tvorby a rozvoje lidského kapitálu jsou podle nich teoretické vědomosti získané zejména na vysoké škole. Studenti by se však měli v současnosti také učit univerzálním dovednostem, mj. vyhledávání informací. Úlohou každé univerzity je najít správný poměr mezi klasickou výukou a využitím elektronických prostředků ve vzdělávání. Pozornost dále autoři věnují intelektuálnímu kapitálu. Jedním z výstupů školního vzdělávání by měla být motivace a schopnost jedince se celoživotně vzdělávat. První kapitola je zakončena úvahou, jaké by měly být dvě základní komponenty univerzitního vzdělávání, aby toto vzdělávání naplnilo roli lidského kapitálu. 
Nad historickými aspekty vývoje a rozvojem univerzitního vzdělávání se autoři zamýšlejí ve druhé kapitole. Informují v historických souvislostech o založení prvních evropských univerzit, a to v Bologni, Paříži, Praze, Bratislavě a následně dalších. Konstatují, že od počátku vzniku univerzit se vedla diskuse o pojetí a významu práce vysokoškolských učitelů a v historické kontinuitě se objevují požadavky na jejich výzkumný talent, mravní, charakterové a osobnostní kvality, spojení se společností, ale i finanční nezávislost aj. Uvádějí př́íklady z dějin univerzitního myšlení, charakterizují univerzity v bohatých zemích a v zemích s nižší úrovní civilizačního rozvoje a v souvislosti s tím seznamují s pojmem „univerzitní optika“. Konstatují, že klasická univerzita přestává existovat v důsledku toho, že nerozvíjí čisté a nekomerční vědy a službu objektivní pravdě, podporovanou osobním př́kladem univerzitního učitele. Definují univerzitní koncept studia, konstatují střety s ekonomickou realitou a nadměrné nadbytečné správní aktivity vedoucí ke ztrátě identity univerzity. Specializovanou součástí vysokoškolských systémů se stávají univerzity výzkumné. Autoři závěrem zdůrazňují, že v každém případě vysoké školy zůstávají hnacím motorem společenského života a pokroku.

Diskuse o pojetí vzdělanosti v současné době je námětem třetí kapitoly. Autoři uvádějí historická pojetí univerzitního vzdělávání a sdělují, že v současné společnosti je vzdělání diskutováno bud' jako tradiční představa o povinných encyklopedických znalostech ve spojení s latinou a řečtinou, nebo je definováno v kompetencích. Současná univerzita by měla být „vědeckým spolkem“ vyučujících a studujících, který má otevřený a liberální charakter. Význam a místo vzdělání v celkovém rozvoji společnosti autoři ukazují po krátkém popisu problémů současného světa. Hlavní metodou vzdělávání z různých příčin zůstává přednáška. Rozpracovávají otázku dalšího vzdělávání, návratnosti investic do vzdělávání i do dalšího vzdělávání.

S vysokoškolským vzděláváním je spojena otázka hodnocení jeho kvality. Hlavním nástrojem jsou národní systémy, v jejichž rámci jsou definovány obsahové a organizační indikátory. Autoři je zmiňují u některých států. V tomto smyslu je zajímavé, že ve Spolkové republice Německo působí několik akreditačních agentur, jež jsou na sobě nezávislé, fungují podle vlastních kritérií a záporné stanovisko jedné neznamená, že další dojde ke stejnému závěru. Rozdíly mezi jednotlivými vysokým školami zveřejňuje řada studií - čtvrtá kapitola seznamuje s jejich výsledky. Autoři uzavírají, že pojem kvality je nespecifický a záleží na hodnotitelích, jaké měřítko příslušnému 
subjektu přiřadí. Ale jak uvádějí, v univerzitním vzdělávání existuje řada věcí, které nelze exaktně změřit, např. osobnostní rozměr vzdělávání.

Pátá kapitola rozpracovává otázku elektronizace univerzitního vzdělávání podle dostupných dat v zahraničí, a to ve spojení s pojednáním o didaktických kompetencích učitele, o vztahu učitel-student, v němž je nedořešená otázka v ohledu didaktických zásad, a o jeho změnách a též o změnách role učitele. Nejen z praxe zahraničních studentů vyplývá, že jejich učení by mělo být zčásti strukturované a systematické a zčásti aktivní, autoregulované. Využití moderních informačních technologií je klíčem k efektivnímu vzdělávání. Proto se prostředky elektronické digitální komunikace stávají dalším systémovým prvkem univerzitního vzdělávání. Autoři nabádají, že je nutné se zamyslet nad tím, jak tyto poznatky u nás využít. Poslední odstavec na s. 63 nevyznívá jednoznačně.

Univerzitnímu vzdělávání v procesu transformace k tržnímu hospodářství je věnována šestá kapitola. Jejím cílem bylo nastínit náměty na ustálení pozice a role vysokých škol v současné společnosti. Autoři dospěli k přesvědčení, že u nás nastala vhodná doba k zahájení širší veřejné diskuse o roli vysokých škol. Identifikují základní rizika, která proces transformace přináší - možné snížení kvality práce vysokých škol spojené s frontálním pojetím výuky ve velkých skupinách a s vysokým počtem absolventů, zejména $\mathrm{v}$ humanitních oborech. Podávají pohled na pravděpodobný vývoj počtu studujících na vysokých školách z hlediska demografického vývoje, podněcují k inspirování našich univerzit v zahraničí. Uvádějí příklady mezinárodní aktivity, zakládání firemních vysokých škol v zahraničí, definují podnikatelskou univerzitu, která by měla vzdělávat budoucí podnikatele, nikoliv zaměstnance. Také však konstatují, že i u nás je možno najít př́́klady dobré praxe, kterými by se mohlo inspirovat zahraničí. Důležitým posuzovatelem aktivity je i publikační činnost vysoké školy. Rozvíjejí se i aktivity v dalším vzdělávání a autoři uvádějí př́klady s jejich krátkou charakteristikou.

Diskusi navrhují koncentrovat do čtyř následujících okruhů: (1) optimální umístění vysokých škol v sociální struktuře, poněvadž i vysoké školy se musí chovat tržně a efektivně. (2) Dalším okruhem je problém kvality vysokoškolského vzdělávání, nástup absolventů na místa, pro která obor vystudovali, a jejich podnikavost. Za tím účelem by se mělo vzdělávání více zaměřovat na výcvik profesních dovedností. (3) Posílení konkurenceschopnosti českých a moravských univerzit je dalším okruhem k diskusi. Vidí ji ve spolupráci s firmami, v určení výzkumných a vzdělávacích univerzit, ve vytvoření 
konsorcia zejména moravských univerzit, v podpoře silné pětky univerzit, které by měly přejít ve výuce na angličtinu podle vzoru Německa. Doporučují vrátit se i k otázce platby školného. Věnují se též otázce technického vzdělávání, jež je trvalým procesem zprostředkování poznatků a komunikace mezi vědou a veřejností. (4) Problém vnitřního řízení vysokých škol je posledním okruhem nabízeným k diskusi. Nejsou pro ně stanoveny žádné požadavky, které by zajistily profesionální řízení. Doporučují zapojit se do problémů, které existují v regionu, v němž škola působí, řešit sponzoring, spolupracovat s místní samosprávou, se spolky a kulturními institucemi.

Historické i současné názory na pojetí vysokoškolského vzdělávání i jejich úlohy ve společnosti dokládají autoři myšlenkami britských a německých filozofů a akademických funkcionářů v poslední kapitole publikace. Tím, že je studium vysoké školy právem pro každého, nikoliv privilegiem pro schopné, podporuje systém „šanci osobního rozvíjení vzděláváním“, kdy vysoké školy směřují k rovnosti dosažené úrovně vzdělání celých populačních skupin, jehož znakem je vazba na hospodářský systém. Vysoké školy jsou tak vystaveny rostoucí poptávce praxe. Znalosti se rozšiřují rychle, ale znalostní zásoby rychleji erodují, což s sebou nese trvalou reorganizaci využití lidského a investičního kapitálu. V závislosti na tom pojednávají o postavení učitelů vysokých škol.

Autoři vyjmenovávají faktory, které ovlivňují akademickou svobodu, dotýkají se i problému „fake news“, mediální manipulace, prosazování new public managementu, což vede $\mathrm{k}$ produkci zaměstnatelných absolventů namísto vedení k podnikatelskému potenciálu studentů. Na závěr přistupují k několika doporučením, s nimiž mnozí nemusí souhlasit, například při hodnocení studujících přihlížet ne k výsledkưm dílčích a státních zkoušek, ale k průběhu studijního procesu a aktivitě studujících. Doporučují perfektní znalost angličtiny ne jako cizího jazyka, ale jako potřebné technické vybavenosti v době internetu.

V závěrečných poznámkách podávají výhledy rozvoje univerzitního vzdělávání, přičemž jedním z prvků rozvoje je jejich diverzifikace systémová, strukturální a programová. Je spojena s distanční formou vzdělávání, poněvadž virtuální výuka rychle reaguje na potřeby zájemců o studium. Fyzická setkání s předními vysokoškolskými pedagogy a odborníky z praxe jsou tím anulována nebo krácena, a tak rozvoj a šiření kultury upadá mezi zbytné věci. „Kamenné univerzity“ však musí na politické a sociálně-ekonomické změny reagovat. 
Monografie pojednává o vysokoškolském vzdělávání, jež má vysokou společenskou závažnost. Je velmi čtivě napsaná, nabitá mnoha informacemi, myšlenkami novými i iznámými, ale v nových souvislostech. Obsah a struktura je dobře promyšlená. Cíle, které si autoři stanovili, v monografii naplnili. Doporučila bych ji všem, kteří jsou s vysokoškolským vzděláváním nějakým způsobem spojeni.

\section{Autor recenze}

doc. PaedDr. Radmila Burkovičová, Ph.D.

Ostravská univerzita, Pedagogická fakulta, Katedra preprimární a primární pedagogiky, Fráni Šrámka 3, 70900 Ostrava, Česká republika email: Radmila.Burkovicova@osu.cz

Přijato: 8. 2. 2021

Link to this article: https://doi.org/10.11118/lifele20211102175 